\title{
Lateral
}

Journal of the Cultural Studies Association

\section{Review of Another Aesthetics is Possible: Arts of Rebellion in the Fourth World War by Jennifer Ponce de León (Duke University Press)}

\author{
by Michael Dango | Book Reviews, Issue 10.2 (Fall 2021)
}

ABSTRACT In Another Aesthetics is Possible, Jennifer Ponce de León looks at recent aesthetic practices in Argentina, Mexico, and the United States that shift the commonsense of history, space, and violence in order to usher in an anticapitalist and anticolonial world. With an expansive archive and a method that combines interviews, journalism, and close formal readings of art-activist practices, Ponce de León demonstrates the importance of aesthetics—and of aesthetic criticism-for making another world possible.

KEYWORDS neoliberalism, performance, social movements, colonialism, aesthetics, gaming, materialism

Another Aesthetics is Possible: Arts of Rebellion in the Fourth World War. By Jennifer Ponce de León. Durham, NC: Duke University Press 2021, 328 pp. (paperback) ISBN 978-1-4780-1125-5. US List: \$27.95.

As global systems of racial capitalist violence entangle with the decimation of the humanities in the neoliberal university, we in cultural studies need to approach aesthetic practices not just as objects of analysis but as theoretical partners that actively bring into view a fuller account of the world and how to fashion a different one. Jennifer Ponce de León's Another Aesthetics is Possible: Arts of Rebellion in the Fourth World War takes on this project in her study of experimental, trans-disciplinary, and collaborative works of media production and interventions in urban space that advance anticapitalist and anticolonial movements in Argentina, Mexico, and the United States from the past twentyfive years.

In four chapters after a theoretical introduction, Ponce de León combines formal readings of aesthetic practices with journalistic coverage and interviews of artists and collaborators. Chapter 1 focuses on the alternate reality game Raiders of the Lost Crown (2013), organized by the Diego de la Vega Cooperative Media Conglomerate and its CEO, Fran Ilich, with the premise of recapturing an Aztec headdress from a museum in Vienna. In the process, it provided a "stereoscopic aesthetics" that enabled players (who interacted both 
in real-world and virtual space) to "[hold] together in a single field of vision the materiality of colonial practices and their systemic disavowal" (36).

Chapter 2 attends to the counter-monuments created by the Pocho Research Society of Erased and Invisible History (PRS), founded by Sandra de la Loza, including the historical plaques erected from 2002-2008 throughout Los Angeles to call attention to Chicanx histories erased by ongoing gentrification and progress narratives, not just displaced "mom and pop" businesses but also queer cruising grounds and other marginalized sex public spaces. In a particularly compelling reading of the text of one plaque, a eulogy for the gay bar The Score written by Ricardo A. Bracho, Ponce de León shows how its queer heightening of somatic and olfactory senses undermines gentrification's visual logics of zoning and beautification.

The book turns to the activities of Etcétera and Grupo de Arte Callejero (GAC) in Buenos Aires in chapters 3 and 4, focusing on different forms of guerrilla urban signage and street theater in the 1990s and early 2000s. GAC evolved the grassroots practice of escraches, which used street signs to publicly shame and harass perpetrators of human rights abuses. This signage not only bypassed the state's rights-based monopoly on justice through community action; it also culture-jammed the state's monopoly on visually "impos[ing] meanings on public spaces and organiz[ing] movement." In doing so, GAC connected a critique of violence under dictatorship with the everyday violence of stateorganized class warfare.Etcétera parodied political theatres-both the spectacles of human rights "truth commissions" and of democratic "electoral pageantry"-through an alternative "materialist theatre" in the tradition of Bertolt Brecht and Augusto Boal that, rather than pacifying its audience with the balm of representation, incites social action (199). Like other groups and artists discussed in this book,Etcétera treats public space as a medium like any other; these are aesthetic practices that work not on canvas but on street, building wall, and supermarket window.

The theoretical import of Ponce de León's analysis of her case studies is captured in her title, Another Aesthetics Is Possible, which borrows from the Zapatistas' assertion that "another world is possible," as well as the claim of one of Ponce de León's interlocutors, Fran llich: "There is no other culture without an other aesthetics, that is to say: an other way of seeing" (48). Aesthetics as a "way of seeing" means, for Ponce de León, not a study of art per se but "the socially forged sensory composition of a world" in which artistic practices actively participate and battle with hegemonic representations of what makes for a literal "common sense": how people intuitively perceive their world.

Throughout the book, Ponce de León affixes domains of experience to this sense of the aesthetic such as an "aesthetics of history" that shapes what is perceived as past versus present, and an "aesthetics of violence" that conditions what even registers as violence in the popular imagination.

The practices Ponce de León studies reorganize the hegemonic common sense of history and violence. For instance, showing how colonial violence is not part of Mexico's past but constitutive of the present neoliberal order, or how official accounts of violence in Argentina limited to political violence under the last dictatorship obscure the ordinariness of state terrorism in the age of security (141). The counter practices also work by affirming 
an alternate world, "producing conditions that allow others to perceive it as a real world" (8). This may sound a lot like Jacques Rancière's "distribution of the sensible"-in which an aesthetic discourse actively delimits what is intelligible and therefore what can be politicized-but for Ponce de León, aesthetics shapes our common sense not just discursively but materially. Ilich's Raiders game, for instance, incorporated a marketplace for Zapatista coffee into its gameplay (63). Ilich also created a cooperative Internet server in 2005, Possible Worlds, a material infrastructure that was an effort, llich says in a phrase again anticipating the book's title, to "practice another internet politics" (48). Ponce de León says of Sandra de la Loza's founding of the PRS, that it "is a meta-artwork . . that also functions as a platform through which she has collaborated with other artists and writers" (81). The production of a "platform" for collaboration-from llich's server to the "embodied pedagogical" theatre of Etcetera-is usually the point of the aesthetic practices surveyed in this book, not just re-distributing the sensible but proliferating physical sites for active political organizing and direct action (168).

The emphasis on material production, and on transforming the mode of production of aesthetic practices themselves, suggests the Marxist influences on Ponce de León's book as well as its subjects. In addition to the Marxist influence on, for instance, the Zapatistas, there is a Marxist aesthetic-theoretical genealogy that makes frequent appearances in the book, from Walter Benjamin on the aestheticization of politics under fascism to, as previously mentioned, Brechtian theatre and its progeny. In the introduction, Ponce de León joins her project not just to Marx but also to "Frantz Fanon, Sylvia Wynter, and others" who "reject the ontological division of biological and social life," but neither of these makes a more than passing reappearance later (4). This is not a criticism, but I was at times left wondering what a fuller engagement with a perspective like Wynter's might also add to the analysis. For instance, Wynter's sense of desire as "a new meta-biological object of knowledge constituted by discourse," which led her to theorize a "rhetorical motivation system" in which aesthetic discourse intervenes at the level of "genetic motivation for organic species," reframes one of the final guerrilla performances Ponce de León analyzes from GAC, Segurí\$mo.1 Enacted in 2003, Segurí\$mo adapted the visual language of supermarket ads to "sell" weapons with histories of repression from colonialism to the contemporary police state. The ads hail a middle class complicit in buying neo-colonialism through their eager support of a private security market. But as Ponce de León narrates, the ads did not blunt this desire: "Some shoppers expressed genuine interest in purchasing the products advertised in GAC's flyer, apparently oblivious to its satirical tone" (225), a consequence she attributes to the fact that the interpolated middle class no longer has an attachment to nonviolence and therefore is not affected by the demystification of a violent state: "The expectation that these things would be morally repugnant to a liberal subject makes sense only within a perspective calibrated to the mythologies, rather than the material history, of liberalism" (226).

Wynter might say that the ads also fail to recalibrate the "rhetorical motivation systems" in which abolishing the police is itself desirable, in part by failing to intervene in the fantasy of security itself. Security is "mythology," to use the term Ponce de León subordinates to "material" history, but Segurí\$mo's taking on a long temporality from colonialism to neoliberalism - which is to say multiple iterations of capitalism and its material realityaffirms this mythology's overdetermination, its relative autonomy from any particular 
reality. It is part of a larger violent rhetorical motivation system that would require cultural battle at the level of, indeed, rhetoric. What would it mean to consider the political failure of aesthetic practices as aesthetic failures, a failure of form and not just a casualty of material history?

It is a testament to the reparative ethos of Another Aesthetics is Possible that Ponce de León allows for little failure in her archive: "Rather than reading Segurísimo as a failed exercise in provoking consciousness-raising discomfort in its audience, it can be read as a realist work (in a Brechtian sense) whose social critique is enriched by consideration of its unexpected reception" (226). The surprisingly passive voice raises the question of who is doing this reading and to whom. This is also a moment of modesty on Ponce de León's part, since who is doing the reading is, of course, the critic, rather than the middle class who failed to be correctly hailed or the GAC who failed to provoke unease.

This book often attributes agency to aesthetic practices-to how they actively reframe the world, rework common sense, incite action-but to some extent, the question of whether these practices succeed at their aim is an empirical question, one for social scientists to take up to determine whether an audience experienced the desired consequences. Where the critic comes in, where the humanist matters, is in working with the aesthetic practiceworking with, but also within and alongside and through — to bring out the formal meanings that could themselves actualize the world they envision.

In an interview with Ponce de León, Sandra de la Loza provides her own view of the politics of art: "No, I don't think art's going to keep the US from bombing Iraq. No, I don't think Siqueiros's murals were going to make the working class rise up and overthrow bourgeois society. I think that's just a simplification of what social change is . . . The impact of an act, a poem, a discourse isn't known until maybe, one, two, three generations afterwards" (110). The role of criticism is to enable this impact, to keep the aesthetic practice alive for one, two, three generations afterwards so it persists as a resource for building another world. Another Aesthetics is Possible is an exemplary model of performing this role.

\section{Notes}

1. Sylvia Wynter, "On Disenchanting Discourse: 'Minority' Literary Criticism and Beyond," Cultural Critique, no. 7 (1987): 229. See also Sylvia Wynter, "Rethinking 'Aesthetics': Notes Towards a Deciphering Practice," in Ex-iles: Essays on Caribbean Cinema, ed. Mbye Cham (Trenton, NJ: Africa World Press, 1992), 237-79. ?

\section{Author Information}

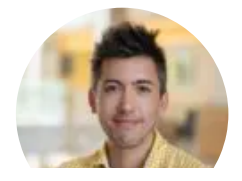

$\underline{\text { Michael Dango }}$ 
Michael Dango is Assistant Professor of English and Media Studies and Affiliated Faculty in Critical Identity Studies at Beloit College. He is the author of Crisis Style: The Aesthetics of Repair (Stanford UP, 2021), which theorizes how stylistic developments in contemporary fiction, sculpture, film, and design respond to a sense of pervasive crisis. He is at work on a second book manuscript, What Does Rape Look Like? Sexual Violence and Aesthetic Education, which argues an aesthetic discourse better understands sexual violence than the legal and public health discourses that have dominated its discussion most recently. Other writings have appeared or are forthcoming in differences, New Literary History, Modern Fiction Studies, Post45, Social Text, Novel, and Signs, as well as para-academic forums such as Public Books, The New Inquiry, The Los Angeles Review of Books, and Artforum.

View all of Michael Dango's articles.

\section{Article details}

Michael Dango, "Review of Another Aesthetics is Possible: Arts of Rebellion in the Fourth World War by Jennifer Ponce de León (Duke University Press)," Lateral 10.2 (2021).

https://doi.org/10.25158/L10.2.24

This article is licensed under a Creative Commons Attribution-NonCommercial 4.0 International License. Copyright is retained by authors.

Lateral is the peer-reviewed, open access journal of the Cultural Studies Association.

ISSN 2469-4053 